\title{
Interpretation of respiratory tract histology in cot deaths
}

\author{
E. TAPP, D. M. JONES, AND J. O'H. TOBIN \\ From the Department of Pathology and The Public Health Laboratory, Withington Hospital, Manchester
}

SYNOPSIS The degree of inflammation in the trachea, bronchi, and lungs of 139 cot deaths has been analysed and each case allocated to one of four groups. In group I the changes were considered to be serious enough to have caused death, while group II cases showed similar abnormalities but of a less severe nature, and in this group there was some doubt as to whether they were a significant cause of death. Group III lesions were very minor in type and were not considered to be serious enough to have resulted in the death of the child. There was a good correlation between the degree of inflammation in the respiratory tract, and whether or not bacteria of any type were grown. The great majority of the bacterial pathogens were isolated from the first two groups. Respiratory viruses were isolated from three of the four cases of acute bronchiolitis included in group I, and also from a group II case which showed considerable bronchiolar inflammation. One-third of the cases with minor inflammation in the lung parenchyma (group III) showed some evidence of recent virus infection.

Many of the babies who die suddenly and unexpectedly have varying degrees of inflammation in the respiratory tracts. As the diagnosis of unexpected death in infancy is by definition one of exclusion, the interpretation of the significance of these lesions is of the utmost importance and consequently there have been numerous papers in the past dealing with this problem. Segard and Koneman (1968) reviewed the significance of laryngotracheobronchitis in sudden death in children and came to the conclusion that this condition should be accepted as one of the anatomical causes of death. These authors point out, however, that there is still a difference of opinion among pathologists about this, and Marshall (1970) was reluctant to accept that the varying degrees of lymphocytic infiltration he found in the submucosa of the trachea and main bronchi were of significance. More recently, Ferris (1974) has emphasized the often minor degrees of inflammatory cell infiltration which have been described around the bronchi and bronchioles in infants dying suddenly and has related these findings in some cases to virus infection. In the present paper an attempt has been made to assess the degree and extent of the inflammation at two sites in the upper and lower respiratory

Received for publication 29 May 1975. tracts and to correlate these changes with the isolation of bacteria and viruses from these sites.

\section{Materials and Methods}

The study was carried out on 139 cases of sudden and unexpected deaths in infancy occurring in the Central Manchester Coroner's area during the years 1970 to 1973 inclusive. The cases represent an annual incidence of 3 per 1000 live births, while the overall postneonatal death rate for this area is 6 per 1000 live births.

All the necropsies were carried out at the Central Police Mortuary by the same pathologist (ET). An exhaustive examination was carried out in each case but the details of the procedure will be described only as far as they apply to the respiratory tract.

After removal of the respiratory organs and heart intact with the structures of the neck, the trachea and main stem bronchi together with a wedge of lung parenchyma to include the hilum were placed in sterile containers for microbiological examination at Withington Hospital. Swabs from the periphery and hilum of the lung were examined for bacteria using standard techniques and those from the trachea and lung parenchyma for virus isolation, using cell cultures and in a few cases for direct immunofluorescence for the presence of respiratory 899 
syncytial virus (RSV). Heart blood was taken from the last 19 cases in the series who died during the winter of 1973-74, for the detection of specific IgM antibody to influenza $A\left(\mathrm{H}_{3} \mathrm{~N}_{2}\right), \mathrm{RSV}$, and parainfluenza 3, by immunofluorescence (De Silva et al, 1973).

Frozen sections of unfixed lung parenchyma from 21 cases were stained with antigammaglobulin conjugate for the presence of immunocytes.

After fixing the lungs in $10 \%$ formol saline for 48 hours a complete coronal slice $5 \mathrm{~mm}$ thick was cut from each lung, and then each slice was divided up entirely into blocks for paraffin embedding. Additional blocks were taken from other parts of the lung if suspicious areas were seen. Histological sections from all the blocks at $5 \mu$ were stained routinely with haematoxylin and eosin.

\section{Results}

\section{HISTOLOGICAL FINDINGS}

The degree of inflammation $(a)$ in the trachea and main bronchi and $(b)$ in the lung parenchyma was classified as follows and the number of cases in each group is given in table $\mathrm{I}$.

\begin{tabular}{llcc}
\hline Group & $\begin{array}{l}\text { Total No. of } \\
\text { Cases }\end{array}$ & \multicolumn{2}{l}{ Lesions } \\
\cline { 3 - 4 } & & Tracheobronchial & Pulmonary \\
\hline I & 20 & $4^{1}$ & 16 \\
II & 21 & 18 & 3 \\
III & 37 & 19 & 18 \\
IV & 61 & 0 & 0 \\
\hline
\end{tabular}

Table I Histological findings

${ }^{1}$ The cases were allocated to a particular group according to the most severe lesion.

\section{Group I}

(a) Acute tracheobronchitis. There was an intense neutrophil polymorph infiltration of the mucosa and submucosa often accompanied by marked oedema and in some cases by necrosis of the mucosa (fig 1).

(b) Acute bronchiolitis, often with necrosis of the bronchiolar epithelium and, in some cases, destruction of the wall of the bronchiole and extension of the inflammation into the surrounding parenchyma (fig 2). Lungs with confluent bronchopneumonia of the bacterial type, with less prominent bronchiolar necrosis but areas where the alveolar air spaces were filled with polymorphs, were also included in this group.

\section{Group II}

(a) A less intense polymorph infiltration of the mucosa with some oedema but no necrosis (fig 3)

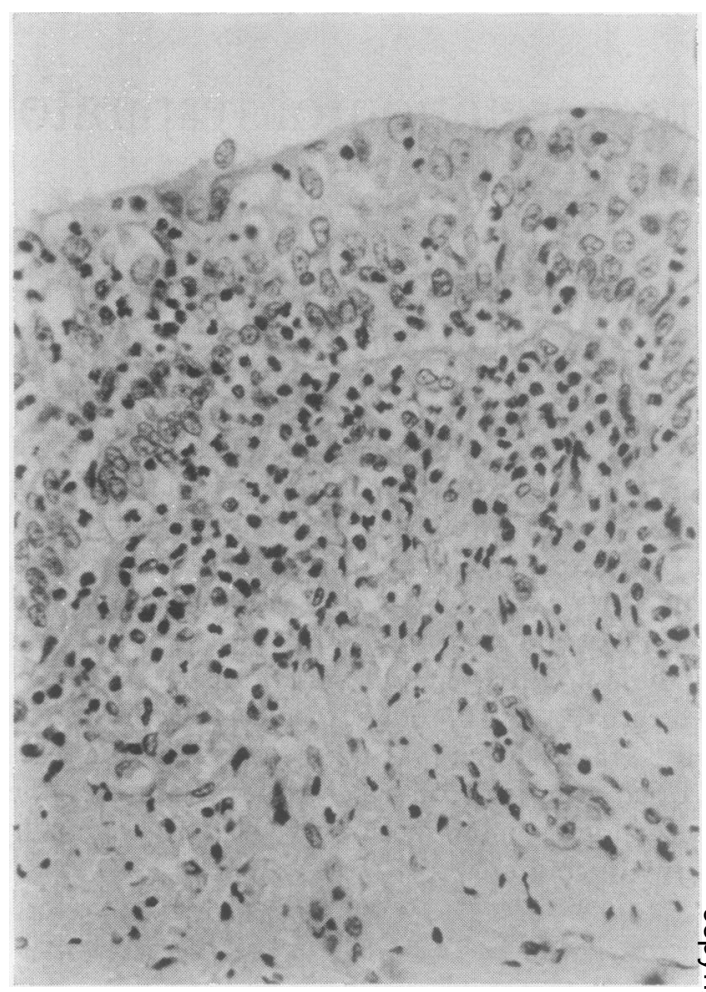

Fig 1 An intense neutrophil polymorph infiltration is seen in the mucosa and submucosa. Haematoxylin and $\operatorname{eosin} \times 305$

(b) Less severe or extensive bronchiolar lesions and lungs where only small areas of bronchopneumonia could be found

\section{Group III}

(a) Mucosa and submucosa containing varying numbers of plasma cells and lymphocytes together with occasional polymorphs (fig 4)

(b) Minor inflammatory lesions around the terminal bronchioles and in the lung parenchyma. In some instances the infiltrate consisted largely of neutrophil polymorphs while in others plasma cells and lymphocytes were predominant (figs 5 and 6).

\section{Group IV}

(a) No inflammation in the trachea or main bronchi

(b) Normal lung parenchyma.

BACTERIOLOGICAL FINDINGS

The bacteria isolated from the lungs in the four main groups are given in table II. Table III shows the 


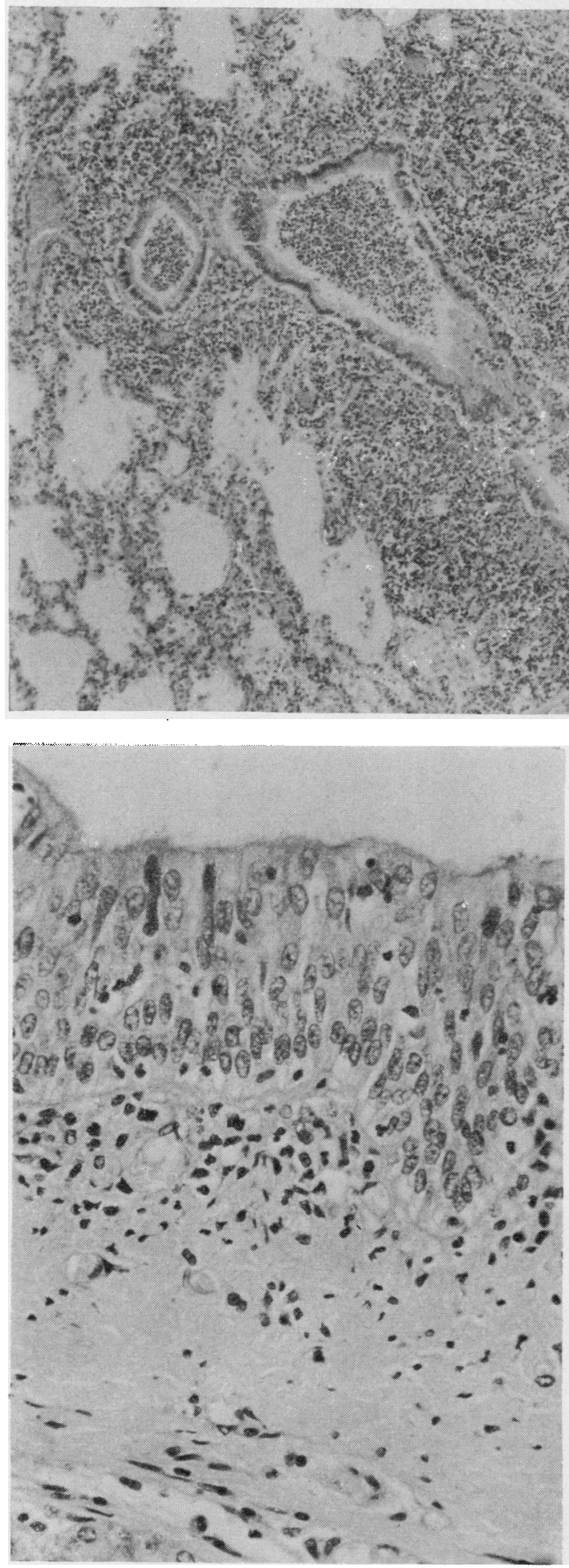

Fig 3

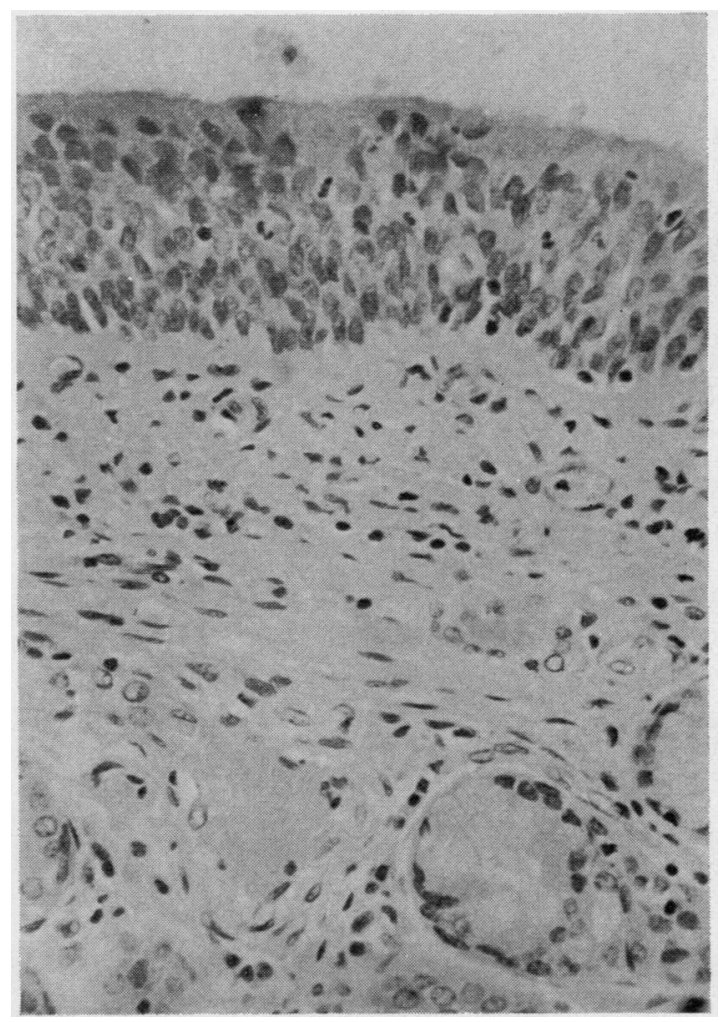

Fig 4

Fig 2 Acute bronchiolitis. $H$ \& $E \times 180$

Fig 3 A less intense polymorph infiltration is seen in this lesion included in group II. $H$ \& $E \times 325$

Fig 4 Varying numbers of lymphocytes and plasma cells together with a few polymorphs are seen in this group III lesion. $H \& E \times 325$ 


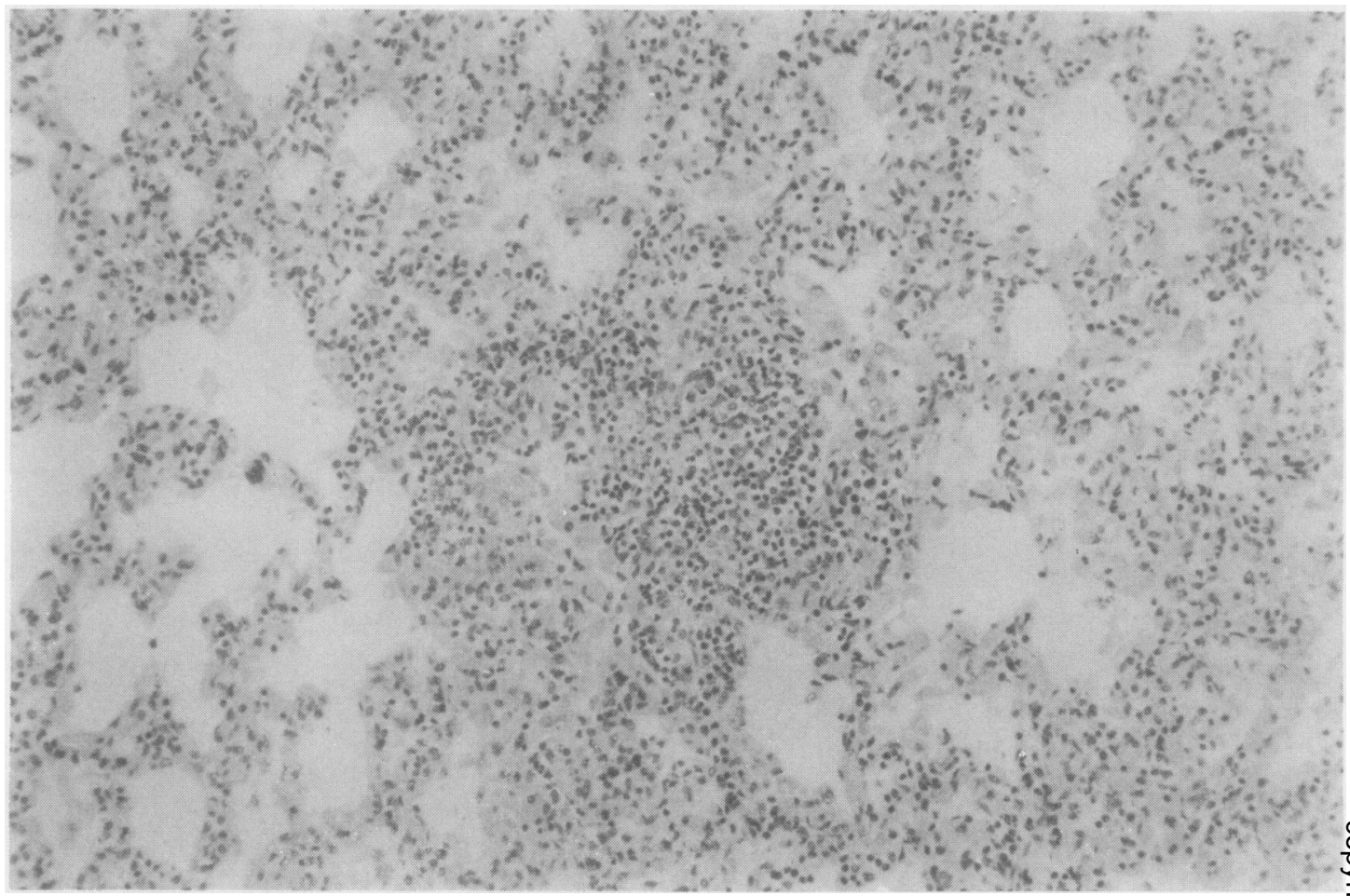

Fig 5 A focus of lymphocytes, plasina cells and polymorphs in the lung parenchyma. $H \& E \times 160$

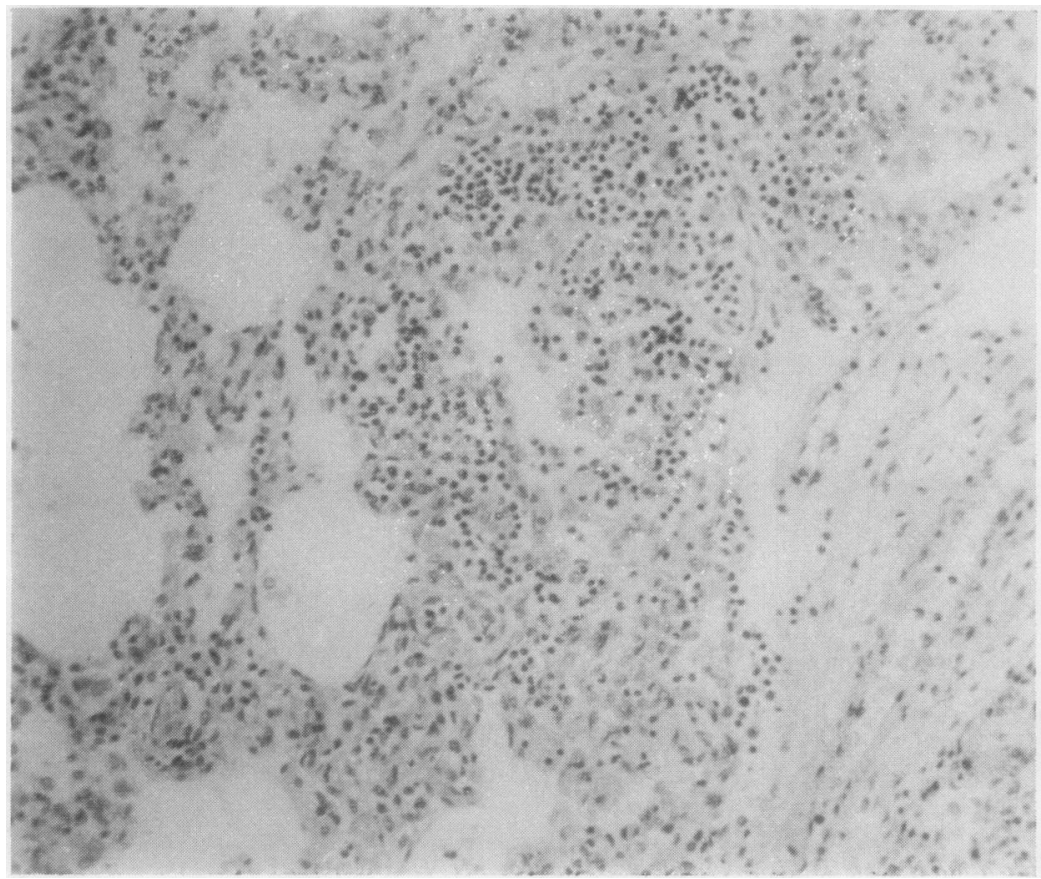

Fig 6 Lymphocytes, plasma cells, polymorphs, and a few histiocytes are seen in the wall of a terminal bronchiole. $H \& E \times 180$ 


\begin{tabular}{llllllc}
\hline Group & Number & $\begin{array}{l}\text { No } \\
\text { Growth }\end{array}$ & $\begin{array}{l}\text { Staph. } \\
\text { aureus }\end{array}$ & $\begin{array}{l}\text { H. } \\
\text { influenzae }\end{array}$ & $\begin{array}{c}\text { Pneumo- } \\
\text { coccus }\end{array}$ & $\begin{array}{l}\text { Str. } \\
\text { viridans }\end{array}$ \\
\hline I & 13 & 2 & 4 & 2 & 1 & 5 \\
II & 15 & 7 & 1 & 4 & 1 & 2 \\
III & 30 & 19 & 1 & 0 & 0 & 11 \\
IV & 30 & 26 & 0 & 0 & 0 & 4 \\
\hline
\end{tabular}

Table II Bacterial isolations

\begin{tabular}{cclllll}
\hline Group & Number & $\begin{array}{l}\text { No } \\
\text { Growth }\end{array}$ & $\begin{array}{l}\text { Staph. } \\
\text { aureus }\end{array}$ & $\begin{array}{l}\text { H. } \\
\text { infuenzae coccus }\end{array}$ & $\begin{array}{l}\text { Pneumo- } \\
\text { Viridans }\end{array}$ \\
\hline Ia & 4 & 0 & 1 & 1 & 0 & 2 \\
b & 9 & 2 & 3 & 1 & 1 & 3 \\
IIa & 13 & 7 & 1 & 4 & 1 & 0 \\
b & 2 & 0 & 0 & 0 & 0 & 2 \\
\hline
\end{tabular}

Table III Bacterial isolations

$a=$ Tracheobronchial lesions

$\mathrm{b}=$ Pulmonary lesions

bacteria isolated from groups I and II according to the site of the histological lesion.

\section{VIRUS ISOLATIONS}

There were few virus isolations, only nine viruses being grown from 114 cultures. The details of these isolations from groups I to III are given in table IV. The three cases from which viruses were isolated in group Ib were all included in this group because of acute bronchiolitis. Attempts to identify specific RSV antigen by immunofluorescence in 30 cases gave negative results using reagents found to be satisfactory for the detection of this virus in nasal aspirates or cell cultures (Cradock-Watson et al, 1971). There were no cases in which both viruses and bacteria were isolated.

\begin{tabular}{|c|c|c|c|}
\hline Lesions & Group I & Group II & Group III \\
\hline $\begin{array}{l}\text { Tracheo- } \\
\text { bronchial }\end{array}$ & $\begin{array}{l}\text { Influenzae A } \\
\left(\mathrm{H}_{3} \mathrm{~N}_{2}\right)\end{array}$ & - & - \\
\hline Pulmonary & $\begin{array}{l}\text { Parainfluenza } 3 \\
\text { Influenzae A } \\
\left(\mathrm{H}_{3} \mathrm{~N}_{2}\right) \\
\text { Herpes simplex }\end{array}$ & Rhinovirus 13 & $\begin{array}{l}\text { Influenzae A } \\
\left(\mathrm{H}_{3} \mathrm{~N}_{2}\right) \\
\text { Adenovirus } 3 \\
\text { Cytomegalo- } \\
\text { virus }\end{array}$ \\
\hline
\end{tabular}

Table IV Virus isolations

\section{SEROLOGICAL FINDINGS}

Antibody suggestive of recent virus infection was found in the serum of 9 of the 19 cases tested (table V). Specific IgM antibody to the respiratory viruses sought was found in cases at the time these viruses were prevalent in the community, and their exact rôle as a cause of death was uncertain. All

\begin{tabular}{lllll}
\hline Group & No. Tested & $R S V$ & $\begin{array}{l}\text { Influenza A } \\
\left(\mathrm{H}_{\mathbf{3}} \mathrm{N}_{\mathbf{2}}\right)\end{array}$ & $\begin{array}{l}\text { Para- } \\
\text { influenza 3 }\end{array}$ \\
\hline I & 1 & 0 & 0 & 0 \\
IIa & 7 & 0 & 1 & 1 \\
b & 0 & 0 & 0 & 0 \\
IIIa & 2 & 1 & 0 & 0 \\
b & 6 & 3 & 1 & 0 \\
IV & 3 & 1 & 1 & 0 \\
\hline
\end{tabular}

Table V Specific IgM antibody to virus in necropsy serum

$a=$ Tracheobronchial lesions

$\mathbf{b}=$ Pulmonary lesions

sera tested had RSV IgG present, but whether this was maternal or acquired could not be determined. No serum gave specific fluorescence to more than one of the three viruses used, suggesting that the reactions were specific and that the infants had had fairly recent infections with these viruses.

A predominance of IgA producing immunocytes was seen. They were mainly around the bronchi, while some IgM and a few IgG producing cells tended to be distributed thinly throughout the lung parenchyma. Because of the difficulty of obtaining any adequate control material in this age group the significance of these findings in relation to response to infection is unknown.

\section{Discussion}

The cases included in group I all had inflammatory lesions of either the trachea, bronchi or lung parenchyma which were so severe as to leave little doubt that they were responsible for death. The lesions in group II were less severe and were such that there was some doubt as to whether these could be the main cause of death. The group III inflammatory lesions were relatively minor in degree and consequently it was felt that they would be extremely unlikely to cause death.

When one considers the pulmonary lesions alone it is apparent that in most instances they were either severe (group I) or very minor (group III), there being only three cases in which there was doubt as to their significance. The reverse applied to the inflammation in the trachea and main bronchi, where there was some doubt as to the relevance of the lesion in 18 of the 22 cases in groups I and II. The significance of varying degrees of inflammation in the trachea and main bronchi has been a problem for many other pathologists in the past and, as Cameron (1969) pointed out, 'although just as it cannot be assumed that severe degrees of tracheitis and bronchitis are the cause of death, so it is by no means certain that minor degrees are without 
lethal significance'. However, in the present study it was felt that a classification into the groups detailed above might be useful when considering the organisms isolated from the respiratory tract.

Table II shows that there is a good correlation between the degree of inflammation and whether or not bacteria of any type are grown. In addition all the recognized bacterial pathogens were isolated from the first two groups, and there seems to be a clear distinction bacteriologically between the cases with considerable inflammation and those with minor degrees. It has already been pointed out that most uncertainty resulting in cases being in group II arose from the lesions of the trachea and main bronchi. In view of this it is interesting that Haemophilus influenzae, a well known respiratory tract pathogen, was prominent in the bacteria isolated from this group (table III).

Representatives of the normal upper respiratory flora were isolated from the lung parenchyma, particularly in group III. It was considered at first that these organisms might have reached the periphery of the lung along with the inhalation of gastric contents but it was found that the isolation of these organisms did not appear to bear any relationship to the degree of inhalation seen histologically.

The small number of virus isolations was probably related to the delay that was often inevitable before the necropsy could be performed. It will be noted, however, that viruses were isolated from three cases included in group Ib because they had acute bronchiolitis. These were out of a total of four cases of acute bronchiolitis in the series. The rhinovirus 13 was also isolated from one of the two cases in group II b where there was considerable bronchiolar inflammation. These findings accentuate the close association between this lesion and virus isolations (Ferris et al, 1973; Downham et al, 1975).
Two respiratory viruses were isolated from the 18 cases which showed relatively minor inflammatory changes around the terminal bronchioles (group III). The serological studies suggested recent virus infection in four of six cases in this group. If these results are added to those for virus isolation, then it is seen that one-third of the cases with minor inflammation of the lung parenchyma have some evidence of recent virus infection. The figures of course are small, but in view of how little is known about these minor inflammatory lesions and of their significance, their relationship to virus infection is worthy of further study.

\section{References}

Cameron, A. H. (1969). Unexpected deaths in infancy. Brit. J. hosp. Med., 2, 1138-1140.

Cradock-Watson, J. E., McQuillin, J., and Gardner, P. S. (1971). Rapid diagnosis of respiratory syncytial virus infection in children by immunofluorescent technique. J. clin. Path., 24, 308-312.

DeSilva, L. M., Khan, M. S., Kampfner, G., Tobin, J. O'H., Gillett, R., and Morris, C. A. (1973). The postmortem diagnosis of influenzal infection by fluorescent IgG, IgA and IgM antibody studies on autopsy blood. J. Hyg. (Lond.), 71, 107-112.

Downham, M. A. P. S., Gardner, P. S., McQuillin, J., and Ferris, J. A. J. (1975). Role of respiratory viruses in childhood mortality. Brit. med. J., 1, 235-239.

Ferris, J. A. J., Aherne, W, A., Locke, W. S., McQuillin, and Gardner, P. S. (1973). Sudden and unexpscted deaths in infancy: Histology and virology. Brit. med.J., 2,439-44

Ferris, J. A. J. (1974). S.I.D.S. 1974, edited by R. R: Robinson, p. 21. The Canadian Foundation for the study of infant deaths. Toronto.

Marshall, T. K. (1970). Sudden Infant Death Syndrome: Proceedings of the 2nd International Conference on Causes of Sudden Death in Infancy, edited by A. B. Bergman, J. B. Beckwith, and C. G. Ray, p. 108. University of Washington Press, Seattle.

Segard, E. C. and Koneman, E. W. (1968). Laryngotracheobronchitis and sudden death in children. Amer. J. clin. Path., 50, 695-699. 